\title{
Synergistic Activity of Mixtures of Piper aduncum Fruit Extract and Three Microorganism-Derived Insecticides against the Diamond Back Moth, Plutella xylostella
}

\author{
Wanda Russianzi ${ }^{1}$, Djoko Prijono ${ }^{2 *}$ \\ ${ }^{1}$ Alumnus of Plant Protection Department, Agriculture Faculty, Institut Pertanian Bogor, Campus IPB Darmaga, Bogor, \\ Indonesia, 16680 \\ ${ }^{2}$ Plant Protection Department, Agriculture Faculty, Institut Pertanian Bogor, Campus Darmaga, Bogor, Indonesia, \\ 16680 \\ ${ }^{*}$ Corresponding author: djokopr@ipb.ac.id
}

\begin{abstract}
Plutella xylostella is an important pest of Brassicaceae vegetable crops. Frequent use of insecticides containing single active ingredients can cause resistance in P. xylostella. This work was done to evaluate the synergism between Piper aduncum fruit extract and three microorganism-derived insecticides, i.e. abamectin, chlorfenapyr, and spinetoram, against $P$. xylostella from Pacet District, Cianjur Regency. Results of leaf-residue feeding bioassays with 48-h feeding treatment showed that $\mathrm{LC}_{95}$ of abamectin, chlorfenapyr, and spinetoram at $96 \mathrm{~h}$ after treatment (HAT) was about 5.8, 7.0, and 1.9-fold higher than their respective field rates. Thus, based on leaf-feeding assays $P$. xylostella larvae from Pacet-Cianjur were not susceptible to abamectin and chlorfenapyr, but were still fairly susceptible to spinetoram. $\mathrm{LC}_{95}$ of $P$. aduncum extract at 96 HAT was $0.68 \%$ (w/v). Based on combination index at the $\mathrm{LC}_{95}$ level - $96 \mathrm{HAT}$, mixtures of $P$. aduncum extract with all three test insecticides were synergistic. Thus, $P$. aduncum extract is potential to be used as an alternative ingredient to increase the effectiveness of the three test insecticides against $P$. xylostella.
\end{abstract}

Keywords: $\quad$ Botanical insecticides, cabbage pest, insecticide mixtures, microorganism-derived insecticides, synergism.

\section{ABSTRAK \\ Aktivitas Sinergistik Campuran Ekstrak Buah Piper aduncum dan Tiga Jenis Insektisida Turunan Metabolit Mikrob terhadap Ulat Plutella xylostella}

Plutella xylostella merupakan hama penting pada tanaman sayuran Brassicaceae. Kebiasaan petani menggunakan insektisida berbahan aktif tunggal dapat menyebabkan hama $P$. xylostella cepat menjadi resisten. Penelitian ini bertujuan mengetahui sinergisme antara ekstrak buah Piper aduncum dan tiga jenis insektisida turunan mikrob, yaitu abamektin, klorfenapir, dan spinetoram, terhadap larva $P$. xylostella dari Kecamatan Pacet, Kabupaten Cianjur, Jawa Barat. Pengujian insektisida dilakukan menggunakan metode celup daun dengan pemberian daun pakan perlakuan selama 48 jam lalu larva diberi pakan daun tanpa perlakuan selama 48 jam berikutnya. Data mortalitas serangga uji diolah dengan analisis probit. Sifat aktivitas setiap campuran ditentukan dengan menghitung indeks kombinasi campuran pada taraf $\mathrm{LC}_{50}$ dan $\mathrm{LC}_{95}$. Hasil pengujian menunjukkan bahwa mortalitas larva $P$. xylostella meningkat tajam antara 24 dan 48 jam setelah perlakuan (JSP). Berdasarkan data mortalitas larva pada 96 JSP, LC $_{95}$ abamektin, klorfenapir, dan spinetoram berturut-turut 5,8; 7,0; dan 1,9 kali lebih tinggi daripada konsentrasi anjuran masing-masing. Dengan demikian berdasarkan hasil pengujian dengan metode celup daun, larva $P$. xylostella asal Pacet-Cianjur sudah tidak rentan terhadap abamektin dan klorfenapir tetapi masih cukup rentan terhadap spinetoram. $\mathrm{LC}_{95}$ ekstrak $P$. aduncum pada 96 JSP adalah $0.68 \%$ (w/v). Berdasarkan indeks kombinasi pada LC $_{95}$-96JSP, campuran ekstrak $P$. aduncum dengan ketiga jenis insektisida turunan mikrob memiliki interaksi sinergistik. Oleh karena itu, ekstrak $P$. aduncum berpotensi digunakan sebagai bahan alternatif untuk meningkatkan keefektifan ketiga jenis insektisida turunan mikrob terhadap P. xylostella.

Kata kunci: $\quad$ Campuran insektisida, hama kubis, insektisida asal mikrob, insektisida nabati, sinergisme.

\section{PENDAHULUAN}

Kubis merupakan komoditas sayuran yang mempunyai arti ekonomi penting sebagai sumber pendapatan petani dan sumber gizi bagi masyarakat (Adiyoga dkk., 2004). Produksi kubis di tingkat nasional dari tahun 2013 sampai 2017 berfluktuasi, yaitu meningkat dari sekitar 1,481 juta ton pada tahun 2013 lalu turun menjadi sekitar 1,436 juta ton pada tahun 2014, meningkat kembali menjadi sekitar 1,443 juta dan 1,513 juta ton pada tahun 2015 dan 2016, tetapi mengalami penurunan menjadi sekitar 1,443 juta ton pada tahun 2017 (Kementan, 2018).

Salah satu kendala biotik dalam budi daya kubis adalah serangan hama ulat daun kubis, Plutella xylostella (L.) (Lepidoptera: Yponomeutidae)
(Grzywacz et al., 2010). Serangan hama tersebut bersama-sama dengan hama kubis lain, yaitu Crocidolomia pavonana (F.) (Lepidoptera: Crambidae), pada musim kemarau dapat menyebabkan kegagalan panen (Sastrosiswojo \& Setiawati, 1993).

Pengendalian hama $P$. xylostella yang dianjurkan di Indonesia adalah dengan menerapkan sistem pengendalian hama terpadu (PHT) (Sastrosiswojo dkk., 2005), tetapi banyak petani kubis yang masih menggunakan insektisida sintetik secara berjadwal (Rauf dkk., 2005). Praktik petani tersebut tidak sesuai dengan konsep PHT dan dapat menimbulkan dampak negatif termasuk berkembangnya populasi hama $P$. xylostella yang 
resisten terhadap insektisida (Moekassan dkk., 2004). Insektisida yang sudah tidak efektif untuk mengendalikan hama pada dosis yang sebelumnya efektif mendorong petani untuk meningkatkan dosis dan frekuensi penggunaan insektisida (Djojosumarto, 2008). Hal tersebut dapat menimbulkan dampak negatif yang lebih besar.

Tiga jenis insektisida di pasaran yang akan diuji dalam penelitian ini ialah abamektin, klorfenapir, dan spinetoram, yang dikembangkan berturut-turut sekitar pertengahan tahun 1970-an, 1980-an, dan 1990-an (Sparks, 2013). Abamektin merupakan insektisida alami yang diisolasi dari hasil fermentasi aktinomiset Streptomyces avermitilis (Pitterna, 2012). Klorfenapir disintesis sebagai turunan dari senyawa dioksapirolomisin hasil fermentasi Streptomyces fumanus (Kuhn \& Armes, 2012). Spinetoram juga merupakan turunan insektisida alami yang berasal dari hasil fermentasi aktinomiset Saccharopolyspora spinosa (Crouse et al., 2012). Abamektin dan spinetoram bekerja sebagai racun saraf sedangkan klorfenapir bekerja sebagai racun respirasi sel (IRAC, 2018). Ketiga insektisida tersebut terdaftar di Indonesia untuk mengendalikan berbagai jenis hama termasuk P. xylostella (Kementan, 2019).

Populasi $P$. xylostella dari beberapa sentra produksi kubis di Jawa dilaporkan sudah tidak rentan terhadap abamektin (Moekasan dkk., 2004; Prijono et al., 2019). Populasi hama tersebut dari Kecamatan Pacet, Kabupaten Cianjur juga dilaporkan sudah tidak rentan terhadap klorfenapir (Prijono et al., 2019). Sementara itu, populasi $P$. xylostella dari beberapa sentra produksi kubis di Jawa Barat dan Jawa Tengah masih rentan terhadap spinetoram (Chenta \& Prijono, 2014; Rakhman \& Prijono, 2015; Prijono et al., 2019).

Keefektifan insektisida dapat menurun bila digunakan secara terus-menerus dan keefektifan insektisida tersebut dapat pulih kembali bila penggunaannya dikurangi atau tidak digunakan lagi untuk mengendalikan hama sasaran yang sama $(\mathrm{Yu}$, 2008). Hal ini juga dapat terjadi pada tiga jenis insektisida turunan mikrob yang diuji. Karena itu, keefektifian insektisida yang digunakan petani di lapangan perlu dipantau secara berkala melalui pengujian toksisitas di laboratorium.

Penurunan keefektifan suatu insektisida dapat terjadi antara lain karena adanya peningkatan metabolisme detoksifikasi oleh berbagai enzim pengurai di dalam tubuh serangga. Salah satu jalur detoksifikasi utama insektisida di dalam tubuh serangga adalah oksidasi bahan aktif insektisida menjadi senyawa yang lebih polar dan kurang beracun oleh enzim polisubstrat monooksigenase (PSMO) (Yu, 2008). Aktivitas enzim tersebut dapat dihambat oleh beberapa jenis senyawa yang disebut sinergis sehingga molekul insektisida akan tetap utuh dan dapat mencapai bagian sasaran di dalam tubuh serangga (Bernard \& Philogène, 1993).
Salah satu sinergis nabati yang akhir-akhir ini sering diteliti ialah dilapiol, yang terdapat dalam daun dan buah sirih hutan, Piper aduncum L. (Bernard et al., 1995; Hasyim, 2011). Selain bersifat sinergis, ekstrak $P$. aduncum dan dilapiol juga bersifat insektisida. Ekstrak buah $P$. aduncum dilaporkan toksik terhadap ulat daun kubis $P$. xylostella (Chenta \& Prijono, 2014) dan ulat krop kubis C. pavonana (Nailufar \& Prijono, 2017) serta bersifat sinergis bila dicampurkan dengan ekstrak buah Sapindus rarak (Syahroni \& Prijono, 2013) dan ekstrak daun Tephrosia vogelii (Nailufar \& Prijono, 2017). Seperti berbagai sinergis lain, dilapiol yang memiliki gugus metilendioksifenil di dalam strukturnya dapat menghambat kerja enzim PSMO (Scott et al., 2008) sehingga insektisida lain yang dicampur dengan dilapiol dapat tetap bekerja mencapai bagian sasaran. Dengan demikian, campuran antara ekstrak buah $P$. aduncum dan setiap jenis insektisida turunan mikrob yang diuji diharapkan bersifat sinergis. Penelitian ini bertujuan menguji aktivitas sinergistik ekstrak $P$. aduncum dalam campuran dengan tiga jenis insektisida turunan mikrob, yaitu abamektin, klorfenapir, dan spinetoram, terhadap larva $P$. xylostella.

\section{BAHAN DAN METODE}

\section{Waktu dan Tempat penelitian}

Penelitian dilaksanakan di Laboratorium Fisiologi dan Toksikologi Serangga, Departemen Proteksi Tanaman, Fakultas Pertanian, Institut Pertanian Bogor (IPB) dari Februari sampai Desember 2017.

\section{Penyiapan Insektisida Uji}

Tiga jenis insektisida turunan mikrob di pasaran yang diuji ialah Agrimec 180 EC (b.a. abamektin $18 \mathrm{~g} / \mathrm{l}$ ), Endure $120 \mathrm{SC}$ (b.a. spinetoram $120 \mathrm{~g} / \mathrm{l}$ ), dan Rampage 100 EC (b.a. klorfenapir 100 $\mathrm{g} / \mathrm{l}$ ), yang diperoleh dari toko pertanian di Bogor. Buah sirih hutan sebagai sumber insektisida nabati yang bersifat sinergis diperoleh dari area kampus Darmaga IPB, Bogor.

\section{Perbanyakan Serangga $P$. xylostella}

Serangga $P$. xylostella yang digunakan dalam penelitian ini merupakan keturunan dari contoh populasi larva yang diambil dari Kebun Pendidikan Pasir Sarongge, Fakultas Pertanian IPB, Kecamatan Pacet, Kabupaten Cianjur. Serangga tersebut diperbanyak di laboratorium mengikuti cara yang dikemukakan oleh Prijono et al. (2019). Secara ringkas, larvanya diberi pakan daun brokoli bebas pestisida yang diperoleh dari kebun organik Bina Sarana Bhakti di Kecamatan Cisarua, Kabupaten Bogor, dan imagonya diberi pakan larutan madu $10 \%$ yang diserapkan pada segumpal kapas. Larva $P$. xylostella instar III dari generasi II atau III digunakan untuk pengujian. 


\section{Ekstraksi Buah P. aduncum}

Buah sirih hutan dipotong kecil-kecil lalu dikeringanginkan selama 1 minggu. Potongan buah sirih hutan digiling dengan menggunakan blender sampai menjadi serbuk. Serbuk buah sirih hutan sebanyak $200 \mathrm{~g}$ direndam dalam pelarut heksana sebanyak $1600 \mathrm{ml}(1: 8, \mathrm{w} / \mathrm{v})$. Perendaman dibiarkan sekurang-kurangnya selama 24 jam dan dilakukan sebanyak tiga kali (Nailufar \& Prijono, 2017). Ekstrak disaring dengan kertas saring Whatman No. 41 dan hasil saringan diuapkan menggunakan rotary evaporator pada suhu $50{ }^{\circ} \mathrm{C}$ dan tekanan 240 mbar. Hasil ekstraksi dibiarkan selama 3 hari di dalam kamar asam lalu dipindahkan ke dalam botol kecil dan disimpan di dalam lemari es (suhu $\pm 4{ }^{\circ} \mathrm{C}$ ) hingga saat digunakan.

\section{Pengujian Toksisitas Insektisida}

Pengujian toksisitas tiga jenis insektisida turunan mikrob dilakukan secara terpisah dengan metode celup daun seperti yang dikemukakan oleh Chenta \& Prijono (2014). Setiap sediaan insektisida diuji pada lima taraf konsentrasi yang diharapkan mengakibatkan kematian serangga uji dari $15 \%$ sampai 95\%. Kisaran konsentrasi uji tersebut ditentukan berdasarkan hasil uji pendahuluan. Konsentrasi uji abamektin berturut-turut 3, 6, 11, 22, dan $42 \mathrm{mg}$ b.a./l; klorfenapir 10, 26, 67, 174, dan 450 mg b.a./l; spinetoram 3, 4.5, 6.7, 10, dan $15 \mathrm{mg}$ b.a./l; serta ekstrak $\quad P$. aduncum $0,1 \%, 0,16 \%, 0,26 \%$, $0,43 \%$, dan $0,7 \%$. Setiap formulasi insektisida uji diencerkan dengan akuades yang mengandung perekat alkilarilpoliglikol eter $80 \mu \mathrm{g} / \mathrm{l}$ (Agristick $400 \mathrm{~L} \mathrm{0,2}$ $\mathrm{ml} / \mathrm{l}$ ). Larutan kontrol berupa akuades yang mengandung perekat Agristik 400 L 0,2. ml/1.

Potongan daun brokoli $4 \mathrm{~cm} \mathrm{x} 4 \mathrm{~cm}$ dicelupkan satu per satu dalam sediaan insektisida uji lalu dikeringanginkan. Dua potongan daun brokoli diletakkan dalam cawan petri yang dialasi tisu, kemudian dimasukkan 10 larva instar III $P$. xylostella dengan lima ulangan. Larva dibiarkan makan daun perlakuan atau daun kontrol selama 2 x 24 jam, kemudian daun perlakuan diganti dengan daun tanpa perlakuan pada 2 x 24 jam berikutnya. Jumlah larva yang mati dicatat setiap hari dari 24 sampai 96 jam setelah perlakuan (JSP).

Ekstrak buah sirih hutan juga diuji toksisitasnya terhadap larva $P$. xylostella. Pengujian juga dilakukan dengan metode celup daun mengikuti prosedur yang dikemukakan oleh Chenta \& Prijono (2014). Ekstrak sirih hutan diencerkan dengan campuran metanol dan pengemulsi Tween 80 (5:1, v/v; konsentrasi akhir 1,2\%), kemudian ditambahkan akuades hingga volume tertentu sesuai konsentrasi pengujian. Larutan kontrol adalah akuades yang mengandung metanol $1 \%$ dan Tween 80 0,2\%. Cara perlakuan, pengamatan, dan analisis data sama seperti pengujian tiga jenis insektisida turunan mikrob di atas.
Ekstrak sirih hutan juga diuji dalam bentuk campuran dengan setiap jenis insektisida turunan minrob pada nisbah konsentrasi 100:1 (dengan abamektin), 40:1 (dengan klorfenapir), dan 140:1 (dengan spinetoram). Cara perlakuan dan pengamatan sama seperti pengujian insektisida secara terpisah.

\section{Analisis Data}

Data mortalitas kumulatif pada 48, 72, dan 96 JSP diolah dengan analisis probit menggunakan program PoloPlus (Robertson et al., 2002-2003). Sifat aktivitas campuran dianalisis dengan menghitung indeks kombinasi (IK) pada taraf $\mathrm{LC}_{50}$ dan $\mathrm{LC}_{95}$ berdasarkan model kerja bersama berbeda (Chou \& Talalay, 1984). Kategori sifat interaksi campuran adalah sebagai berikut (Chou \& Talalay, 1984): (a) bila IK $=1$, komponen campuran bersifat aditif; (b) IK $<1$, komponen campuran bersifat sinergistik; (c) bila $\mathrm{IK}>1$, komponen campuran bersifat antagonistik.

\section{HASIL DAN PEMBAHASAN}

\section{Toksisitas Insektisida Turunan Mikrob dan Ekstrak Secara Tunggal}

Secara umum perlakuan dengan insektisida turunan mikrob dan ekstrak $P$. aduncum secara terpisah menyebabkan kematian $P$. xylostella yang meningkat seiring bertambahnya waktu pengamatan dan makin tingginya konsentrasi insektisida yang diuji (Gambar 1). Secara keseluruhan mortalitas larva meningkat pada 24 dan 48 JSP baik pada perlakuan insektisida turunan mikrob maupun insektisida nabati, sedangkan antara 48 dan 96 JSP hanya terjadi sedikit peningkatan kematian serangga uji. Hal tersebut terjadi karena perlakuan diberikan pada 48 jam pertama sedangkan pada 48 jam berikutnya serangga uji diberi daun pakan tanpa perlakuan.

Berdasarkan hasil analisis probit, $\mathrm{LC}_{50}$ dan $\mathrm{LC}_{95}$ semua insektisida uji pada 48, 72, dan 96 JSP semakin kecil (tingkat toksisitas makin tinggi) dengan bertambahnya waktu pengamatan (Tabel 1). Hal tersebut sesuai dengan pola perkembangan mortalitas serangga uji (Gambar 1) yang masih meningkat antara 48 dan 96 JSP. Berdasarkan tingkat toksisitas pada taraf $\mathrm{LC}_{50}-96 \mathrm{JSP}$, insektisida spinetoram paling toksik terhadap larva $P$. xylostella diikuti abamektin, dan klorfenapir; sedangkan berdasarkan $\mathrm{LC}_{95}-96$ JSP, insektisida abamektin paling toksik terhadap larva $P$. xylostella diikuti spinetoram, dan klorfenapir.

Perbedaan pola toksisitas di antara ketiga jenis insektisida turunan mikrob pada taraf $\mathrm{LC}_{50}$ dan $\mathrm{LC}_{95}$ pada 96 JSP diduga karena adanya perbedaan sifat kimia masing-masing insektisida dan interaksinya dengan bagian sasaran ( $\mathrm{Yu}, 2008)$. Bagian sasaran abamektin adalah saluran klorida yang diaktifkan glutamat pada membran saraf pascasinapsis, klorfenapir - sistem gradien proton terkait sintesis ATP pada membran dalam mitokondria, dan spinetoram - reseptor asetilkolin pada membran saraf 

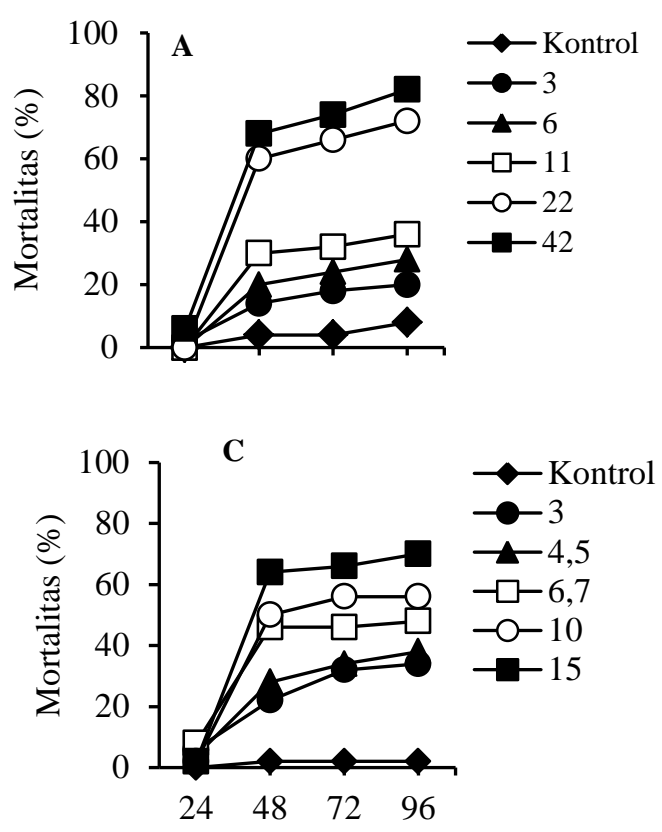

Waktu pengamatan (JSP)

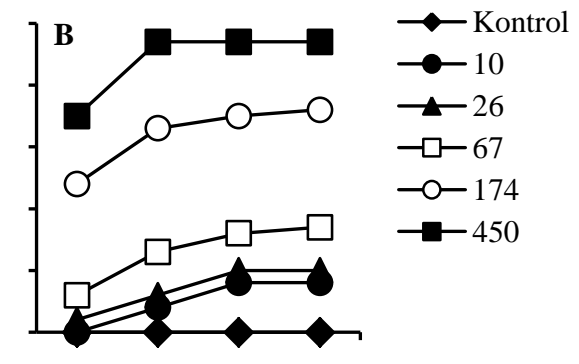

D

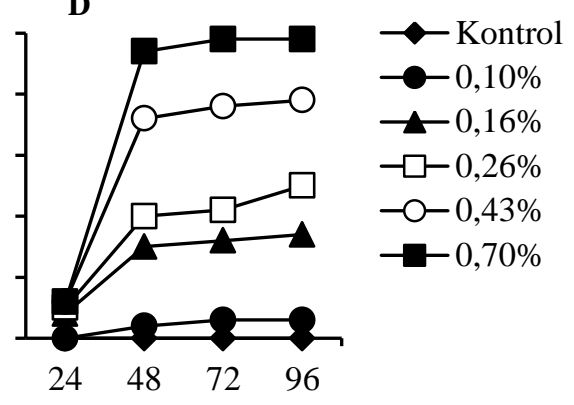

Waktu pengamatan (JSP)

Gambar 1. Perkembangan tingkat mortalitas larva P. xylostella pada perlakuan abamektin (A), klorfenapir (B), spinetoram (C), dan ekstrak P. aduncum (D). Satuan pada legenda adalah mg b.a./l untuk tiga jenis insektisida turunan mikrob.

(IRAC, 2018). Interaksi antara spinetoran dan bagian sasarannya pada taraf setara $\mathrm{LC}_{50}$ tampaknya paling kuat dibandingkan dengan interaksi antara abamektin dan klorfenapir dengan bagian sasaran masingmasing. Sementara itu, pada konsentrasi yang setara dengan $\mathrm{LC}_{95}$ interaksi antara abamektin dan bagian sasarannya paling kuat dibandingkan dengan interaksi antara klorfenapir dan spinetoram dengan bagian sasaran masing-masing. Ekstrak $P$. aduncum memiliki nilai $\mathrm{LC}_{50}$ pada $96 \mathrm{JSP}$ sebesar $2408.26 \mathrm{mg} / \mathrm{l}$ atau sebesar $0,24 \%$, sementara $\mathrm{LC}_{95}$ pada 96 JSP sebesar $6837 \mathrm{mg} / \mathrm{l}$ atau sekitar 0,68\% (w/v) (Tabel 1). Hal ini menunjukkan bahwa ekstrak tersebut kurang efektif bila digunakan secara tunggal terhadap hama $P$. xylostella di lokasi pengambilan sampel serangga (Kecamatan Pacet, Cianjur). Ekstrak tumbuhan dikatakan layak digunakan di lapangan bila pada konsentrasi tidak lebih dari $0,5 \% \quad(w / v)$ dapat mematikan hama sasaran sekurang-kurangnya $80 \%$ (Dadang \& Prijono, 2008).

Nilai $\mathrm{LC}_{95}$ abamektin, klorfenapir, dan spinetoram pada 96 JSP berturut-turut 5,8; 7,0; dan 1,9 kali lebih tinggi daripada konsentrasi anjuran yang tertera pada label kemasan formulasi insektisida tersebut. Hal tersebut menunjukkan bahwa berdasarkan hasil pengujian dengan metode celup daun, larva $P$. xylostella asal Kecamatan Pacet, Kabupaten Cianjur tidak rentan terhadap abamektin dan klorfenapir tetapi masih cukup rentan terhadap spinetoram.
Perbedaan kerentanan tersebut karena petani di Pasir Sarongge, Pacet, Cianjur sudah lebih sering menggunakan insektisida berbahan aktif abamektin dan klorfenapir daripada spinetoram yang pemasarannya lebih akhir.

Ketidakrentanan P. xylostella dari Jawa Barat terhadap abamektin dan klorfenapir sudah pernah dilaporkan sebelumnya, misalnya oleh Moekasan dkk., (2004) dan Prijono et al., (2019). Sebaliknya, beberapa penelitian menunjukkan bahwa populasi $P$. xylostella dari beberapa daerah di Jawa Barat dan Jawa Tengah masih rentan terhadap spinetoram (Chenta \& Prijono, 2014; Rakhman \& Prijono, 2015; Prijono et al., 2019).

\section{Toksisitas Campuran Insektisida Turunan Mikrob dan Ekstrak P. aduncum}

Seperti pada perlakuan insektisida uji secara terpisah, perlakuan dengan campuran antara insektisida turunan mikrob dan ekstrak $P$. aduncum juga mengakibatkan mortalitas larva $P$. xylostella yang meningkat tajam hingga 48 JSP kemudian terjadi peningkatan mortalitas dalam proporsi yang lebih rendah antara 48 dan 96 JSP (Gambar 2). LC $_{50}$ dan $\mathrm{LC}_{95}$ ketiga jenis campuran pada 48, 72, dan 96 JSP juga semakin kecil (tingkat toksisitas semakin tinggi) dengan bertambahnya waktu pengamatan (Tabel 2) yang sesuai dengan pola perkembangan mortalitas serangga uji yang ditunjukkan pada Gambar 2.

Selain itu, $\mathrm{LC}_{50}$ dan $\mathrm{LC}_{95}$ ketiga jenis campuran tersebut pada semua waktu pengamatan 
(Tabel 2) lebih rendah dibandingkan dengan $\mathrm{LC}_{50}$ dan $\mathrm{LC}_{95} P$. aduncum secara terpisah (Tabel 1). Hal tersebut mencerminkan terjadinya peningkatan toksisitas di dalam campuran antara ekstrak $P$. aduncum dan ketiga jenis insektisida turunan mikrob. Indeks kombinasi campuran ekstrak $P$. aduncum dan abamektin serta ekstrak $P$. aduncum dan klorfenapir pada taraf $\mathrm{LC}_{50}$ menunjukkan aktivitas yang bersifat

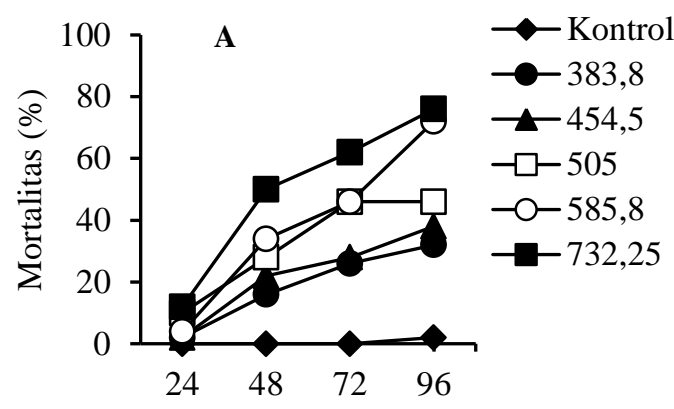

Waktu pengamatan (JSP)

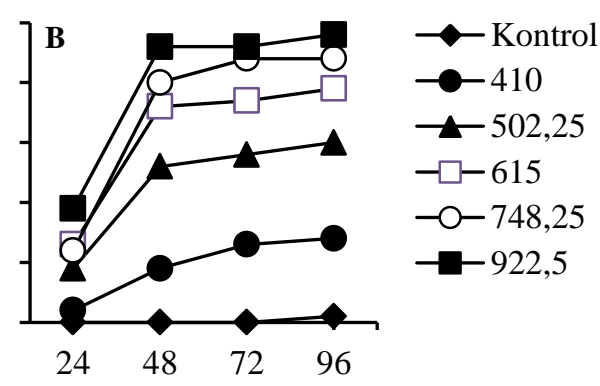

Waktu pengamatan (JSP)

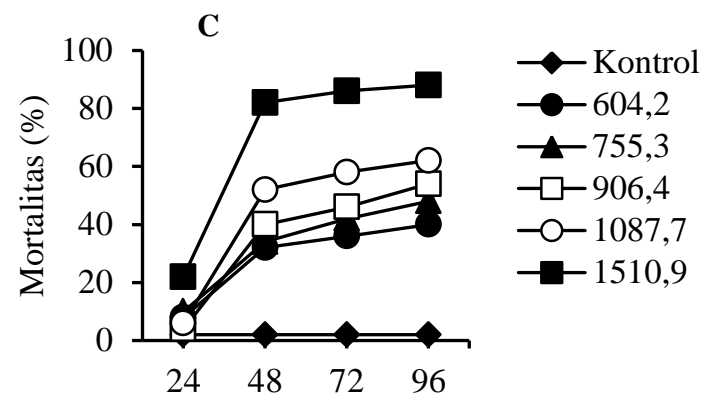

Waktu pengamatan (JSP)

Gambar 2. Perkembangan tingkat mortalitas larva $P$. xylostella pada perlakuan campuran abamektin $+P$. aduncum [P.a.] (A), klorfenapir + P.a. (B), dan spinetoram + P.a. (C). Satuan pada legenda adalah $\mathrm{mg} / \mathrm{l}$.

sinergistik, sedangkan campuran ekstrak $P$. aduncum dan spinetoram bersifat aditif (Tabel 3). Ketiga jenis campuran ekstrak $P$. aduncum dengan abamektin, klorfenapir, dan spinetoram bersifat sinergistik pada taraf $\mathrm{LC}_{95}$. Hal tersebut menunjukkan bahwa spinetoram memerlukan senyawa sinergis pada proporsi yang lebih tinggi daripada abamektin dan klorfenapir.

Sifat sinergistik ketiga campuran tersebut di atas diduga disebabkan oleh dilapiol yang terkandung dalam ekstrak buah P. aduncum (Hasyim, 2011). Senyawa tersebut selain bersifat insektisida juga bersifat sinergis (Bernard et al., 1990; Bernard et al., 1995). Dilapiol dapat menghambat proses oksidasi di dalam sel yang

yang dikatalisis oleh enzim PSMO (Scott et al., 2008). Hambatan terhadap aktivitas enzim tersebut mengakibatkan insektisida lain yang dicampurkan dengan ekstrak $P$. aduncum yang mengandung dilapiol dapat terhindar dari penguraian oleh enzim
PSMO sehingga insektisida tersebut dapat tetap bekerja meracuni bagian sasaran.

Insektisida yang sudah tidak efektif terhadap P. xylostella, seperti abamektin dan klorfenapir, dapat dipulihkan keefektifannya dengan menghentikan penggunaannya selama beberapa waktu dan setelah kembali cukup efektif, penggunaannya dapat dicampur dengan insektisida lain, termasuk yang bersifat sinergis seperti ekstrak $P$. aduncum, untuk mencegah terjadinya resistensi lebih lanjut (Leeper et al., 1986). Penggunaan campuran insektisida akan lebih bermanfaat dalam pengelolaan resistensi insektisida bila hama belum resisten terhadap komponen campuran (EPPO, 2018). Terkait dengan hal tersebut, penggunaan spinetoram yang dicampur dengan ekstrak $P$. aduncum yang bersifat sinergis diharapkan dapat memperlambat terjadinya resistensi $P$. xylostella terhadap insektisida tersebut atau mempertahankan keefektifan insektisida tersebut terhadap P. xylostella. 
Tabel 1. Hasil analisis probit uji toksisitas tiga jenis insektisida turunan mikrob dan ekstrak buah P. aduncum terhadap larva P. xylostella asal Pasir Sarongge, Kecamatan Pacet, Kabupaten Cianjur

\begin{tabular}{|c|c|c|c|c|c|}
\hline Insektisida & $\begin{array}{c}\text { Konsentrasi } \\
\text { anjuran (mg b.a./l) }\end{array}$ & $\begin{array}{c}\text { Waktu } \\
\text { Pengamatan } \\
\text { (JSP) }^{\mathrm{b}}\end{array}$ & $b \pm \mathrm{GB}^{\mathrm{c}}$ & $\mathrm{LC}_{50}(\mathrm{SK} 95 \%), \mathrm{mg}$ b.a./ $\mathrm{l}^{\mathrm{d}}$ & $\mathrm{LC}_{95}(\mathrm{SK} 95 \%), \mathrm{mg}$ b.a. $/ \mathrm{l}^{\mathrm{d}}$ \\
\hline \multirow[t]{3}{*}{ Abamektin } & 18 & 48 & $1,649 \pm 0,262$ & $21,04(16,88-27,60)$ & $208,89(107,05-720,36)$ \\
\hline & & 72 & $1,647 \pm 0,252$ & $17,11(11,10-30,47)$ & $170,60(69,03-2185,54)$ \\
\hline & & 96 & $1,949 \pm 0,292$ & $14,89(11,70-19,05)$ & $103,91(63,48-247,14)$ \\
\hline \multirow[t]{3}{*}{ Klorfenapir } & 125 & 48 & $1,854 \pm 0,196$ & $101,53(51,00-240,93)$ & $782,70(301,62-14971)$ \\
\hline & & 72 & $1,524 \pm 0,172$ & $78,99(31,29-241,61)$ & $947,27\left(285,89-12,15 \times 10^{3}\right)$ \\
\hline & & 96 & $1,544 \pm 0,173$ & $75,74(32,27-201,85)$ & $879,79(284,43-50289)$ \\
\hline \multirow[t]{4}{*}{ Spinetoram } & 60 & 48 & $1,677 \pm 0,353$ & $9,48(7,53-13,46)$ & $90,71(41,97-561,71)$ \\
\hline & & 72 & $1,369 \pm 0,342$ & $8,11(6,14-11,92)$ & $128,91(47,89-2203,1)$ \\
\hline & & 96 & $1,365 \pm 0,341$ & $7,27(5,41-10,20)$ & $116,58(36,957-20556)$ \\
\hline & & & & $\mathrm{LC}_{50}(\mathrm{SK} 95 \%)(\mathrm{mg}$ ekstrak/l) & $\mathrm{LC}_{95}(\mathrm{SK} 95 \%)(\mathrm{mg}$ ekstrak/l) \\
\hline \multirow[t]{3}{*}{ Ekstrak $P$. aduncum } & 60 & 48 & $3,419 \pm 0,368$ & $2755,0(2117,7-3625,2)$ & $8340,4(5628,7-19848)$ \\
\hline & & 72 & $3,600 \pm 0,382$ & $2550,4(1897,7-3438,5)$ & $7302,5(4890,3-19210)$ \\
\hline & & 96 & $3,629 \pm 0,386$ & $2408,3(1894,9-3038,7)$ & $6837,0(4867,0-13621)$ \\
\hline
\end{tabular}

${ }^{\mathrm{a} B}$ Berdasarkan dosis atau konsentrasi anjuran (Kementan, 2019. ${ }^{\mathrm{b}} \mathrm{JSP}=$ jam setelah perlakuan. ${ }^{\mathrm{c}} b=$ kemiringan garis regresi probit; GB $=$ galat baku. ${ }^{\mathrm{d}} \mathrm{SK}=$ selang kepercayaan.

Tabel 2. Hasil analisis probit uji toksisitas campuran tiga jenis insektisida turunan mikrob dan ekstrak buah P. aduncum (Pa) terhadap larva $P$. xylostella

\begin{tabular}{|c|c|c|c|c|}
\hline Campuran & $\begin{array}{c}\text { Waktu } \\
\text { pengamatan (JSP) }\end{array}$ & $b \pm \mathrm{GB}^{\mathrm{b}}$ & $\begin{array}{c}\mathrm{LC}_{50}(\mathrm{SK} 95 \%) \\
\mathrm{mg} / \mathrm{l}^{\mathrm{c}}\end{array}$ & $\begin{array}{c}\mathrm{LC}_{95}(\mathrm{SK} 95 \%) \\
\mathrm{mg} / \mathrm{l}^{\mathrm{c}}\end{array}$ \\
\hline \multirow{3}{*}{$\begin{array}{l}\mathrm{Pa}+\text { abamektin } \\
(100: 1)\end{array}$} & 48 & $3,537 \pm 0,899$ & $744,4(644,7-1070,5)$ & $2171,7(1350,5-8816,3)$ \\
\hline & 72 & $3,489 \pm 0,864$ & $601,5(540,7-728,3)$ & $1781,1(1183,3-5698,3)$ \\
\hline & 96 & $4,864 \pm 0,913$ & $506,1(463,5-548,9)$ & $1102,4(889,7-1731,3)$ \\
\hline \multirow{3}{*}{$\begin{array}{l}\mathrm{Pa}+\text { klorfenapir } \\
(40: 1)\end{array}$} & 48 & $6,252 \pm 0,798$ & $526,3(447,3-590,1)$ & $964,6(803,6-1477,5)$ \\
\hline & 72 & $6,057 \pm 0,809$ & $495,0(451,9-531,1)$ & $925,0(822,5-1117,0)$ \\
\hline & 96 & $6,542 \pm 0,864$ & $481,1(440,1-514,9)$ & $858,4(771,8-1015,8)$ \\
\hline \multirow{3}{*}{$\begin{array}{l}\mathrm{Pa}+\text { spinetoram } \\
(140: 1)\end{array}$} & 48 & $3,521 \pm 0,651$ & $974,0(756,1-1372,8)$ & $2855,6(1761,4-38791)$ \\
\hline & 72 & $3,489 \pm 0,654$ & $877,2(655,1-1106,4)$ & $2596,8(1670,0-19563)$ \\
\hline & 96 & $3,366 \pm 0,657$ & $798,3(683,8-894,1)$ & $2459,0(1832,1-4660,3)$ \\
\hline
\end{tabular}

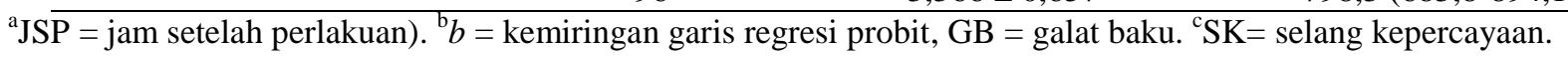


Tabel 3. Sifat aktivitas campuran tiga jenis insektisida turunan mikrob dan ekstrak buah P. aduncum (Pa) terhadap larva P. xylostella

\begin{tabular}{|c|c|c|c|c|c|}
\hline \multirow{2}{*}{ Campuran } & \multirow{2}{*}{$\begin{array}{c}\text { Waktu } \\
\text { pengamatan } \\
(\text { JSP })^{\mathrm{a}}\end{array}$} & \multicolumn{2}{|c|}{ Indeks kombinasi } & \multicolumn{2}{|c|}{ Sifat interaksi } \\
\hline & & $\mathrm{LC}_{50}$ & $\mathrm{LC}_{95}$ & $\mathrm{LC}_{50}$ & $\mathrm{LC}_{95}$ \\
\hline \multirow{3}{*}{$\begin{array}{l}\mathrm{Pa}+ \\
\text { abamektin } \\
(100: 1)\end{array}$} & 48 & 0,71 & 0,39 & Sinergistik & Sinergistik \\
\hline & 72 & 0,66 & 0,37 & Sinergistik & Sinergistik \\
\hline & 96 & 0,61 & 0,28 & Sinergistik & Sinergistik \\
\hline \multirow{3}{*}{$\begin{array}{l}\mathrm{Pa}+ \\
\text { klorfenapir } \\
(40: 1)\end{array}$} & 48 & 0,34 & 0,15 & Sinergistik & Sinergistik \\
\hline & 72 & 0,37 & 0,15 & Sinergistik & Sinergistik \\
\hline & 96 & 0,38 & 0,15 & Sinergistik & Sinergistik \\
\hline \multirow{3}{*}{$\begin{array}{l}\mathrm{Pa}+ \\
\text { spinetoram } \\
(140: 1)\end{array}$} & 48 & 1,33 & 0,64 & Aditif & Sinergistik \\
\hline & 72 & 1,37 & 0,55 & Aditif & Sinergistik \\
\hline & 96 & 1,36 & 0,56 & Aditif & Sinergistik \\
\hline
\end{tabular}

Selain itu, penggunaan campuran yang bersifat sinergis terhadap hama sasaran dapat menurunkan dosis aplikasi insektisida sehingga dapat memperkecil kemungkinan dampak negatif terhadap organisme bukan sasaran. Spinetoram termasuk insektisida yang cukup aman dan di Amerika Serikat sudah terdaftar sebagai pestisida berisiko rendah (reduced-risk pesticides) (EPA, 2018). Dengan demikian, penggunaan spinetoram dalam dosis yang lebih rendah bila dicampur dengan ekstrak $P$. aduncum akan makin meningkatkan tingkat keamanan insektisida tersebut dan diharapkan dapat mendukung penerapan PHT pada tanaman kubis.

\section{KESIMPULAN}

Berdasarkan hasil pengujian dengan metode celup daun, larva P. xylostella asal Kecamatan Pacet, Kabupaten Cianjur, Jawa Barat, tidak rentan terhadap abamektin dan klorfenapir, tetapi masih cukup rentan terhadap spinetoram. Campuran ketiga jenis insektisida tersebut dengan ekstrak $P$. aduncum bersifat sinergistik sehingga penambahan ekstrak $P$. aduncum berpotensi memperlambat terjadinya resistensi $P$. xylostella terhadap insektisida yang masih efektif.

\section{UCAPAN TERIMA KASIH}

Penulis mengucapkan terima kasih kepada pengelola kebun organik Bina Sarana Bhakti, Cisarua, Bogor, atas izin untuk mendapatkan daun brokoli bebas pestisida sebagai pakan serangga.

\section{DAFTAR PUSTAKA}

Adiyoga, W., M. Ameriana, R. Suherman, T.A. Soetiarso, B. Jaya, B.K. Udiarto, R. Rosliani, \& D. Mussadad. 2004. Profil Komoditas Kubis. Bandung: Balai Penelitian Tanaman Sayuran.

Bernard, C.B., J.T. Arnason, B.J.R. Philogène, J. Lam, \& T. Waddell. 1990. In vivo effect of mixtures of allelochemicals on the life cycle of the
European corn borer, Ostrinia nubilalis. Entomol. Exp. Appl. 57(1): 17-22.

Bernard, C.B., H.G. Krishnamurty, D. Chauret, T. Durst, B.J.R. Philogène, V.P. Sanchez, C, Hasbun, L. Poveda, R.L. San, \& J.T. Arnason. 1995. Insecticidal defenses of Piperaceae from the Neotropics. J. Chem. Ecol. 21(6): 801-814.

Bernard, C.B., \& B.J.R. Philogène. 1993. Insecticide synergists: role, importance, and perspectives. J. Toxicol. Environ. Health. 38(2): 199-223.

Chenta, W.E.L., \& D. Prijono. 2014. Kerentanan Plutella xylostella dari Kejajar Dieng, Kabupaten Wonosobo, Jawa Tengah terhadap lima jenis insektisida komersial dan ekstrak buah Piper adunctum. Pp. 673-679 in Prosiding Seminar Nasional dan Rapat Tahunan Dekan Bidang Ilmu Pertanian, BKSPTN Wilayah Barat; Bandar Lampung, 19-21 Agustus 2014. Bandar Lampung: Fakultas Pertanian, Universitas Lampung.

Chou, T.C., \& P. Talalay. 1984. Quantitative analysis of dose-effect relationships: the combined effects of multiple drugs or enzyme inhibitors. Adv. Enzyme Regl. 22: 27-55.

Crouse, G.D., J.E. Dripps, T.C. Sparks, G.B. Watson, \& C. Waldron. 2012. Spinosad and spinetoram, a new semi-synthetic spinosyn. Pp. 1238-1257 in Krämer, W, Schirmer, U., Jeschke, P., \& Witschel, W. (Eds.). Modern Crop Protection Compounds. 2nd ed. Weinheim: Wiley-VCH.

Dadang, \& D. Prijono. 2008. Insektisida Nabati: Prinsip, Pemanfaatan, dan Pengembangan. Bogor: Departemen Proteksi Tanaman, Institut Pertanian Bogor.

Djojosumarto, P. 2008. Pestisida dan Aplikasinya. Jakarta: AgroMedia Pustaka.

[EPA] United States Environmental Protection Agency. 2018. Pesticide registration: reduced risk and organophosphate alternative decisions for conventional pesticides. Tersedia di http://www.epa.gov/pesticideregistration/reduced-risk-and- 
organophosphate-alternative-decisions-

conventional; diakses pada 27 Agustus 2018.

[EPPO] European and Mediterranean Plant Protection Organization. 2018. PP 1/306 (1) General principles for the development of coformulated mixtures of plant protection products. EPPO Bull. 0: 1-9.

Grzywacz, D., A. Rossbach, A. Rauf, D.A. Russell, R. Srinivasan, \& A.M. Shelton. 2010. Current control methods for diamondback moth and other brassica insect pests and the prospects for improved management with Lepidopteranresistant $\mathrm{Bt}$ vegetable brassicas in Asia and Africa. Crop Prot. 29(1): 68-79.

Hasyim, D.M. 2011. Potensi buah sirih hutan (Piper aduncum) sebagai insektisida botani terhadap larva Crocidolomia pavonana. Tesis. Bogor: Institut Pertanian Bogor.

[IRAC] Insecticide Resistance Action Committee 2018. IRAC Mode of Action Classification Scheme Version 9.1. Tersedia di http://www.irac-online.org/ documents/moaclassification/?ext=pdf; diakses pada 29 Januari 2019.

[Kementan] Kementerian Pertanian Republik Indonesia. 2018. Produksi Tanaman Sayuran Kubis. Tersedia

https://aplikasi2.pertanian.go.id/bdsp/id/

komoditas; diakses pada 14 Januari 2019.

[Kementan] Kementerian Pertanian Republik Indonesia. 2019. Sistem Informasi Pestisida. Tersedia di http://pestisida.id/simpes_app/ rekap_komoditas_formula.php?s_keyword=plu tella+xylostella; diakses pada 12 Februari 2019.

Kuhn, D., \& N. Armes. 2012. Inhibitors of oxidative phosphorylation via disruption of the proton gradient. Pp. 1070-1077 in Krämer, W, Schirmer, U., Jeschke, P., \& Witschel, W. (Eds.). Modern Crop Protection Compounds. 2nd ed. Weinheim: Wiley-VCH.

Leeper, J.R., R.T. Roush, \& H.T. Reynolds. 1986. Preventing or managing resistance in Arthropods. Pp. 335-346. In Committee on Strategies for the Management of Pesticide Resistant Pest Populations. Pesticide Resistance: Strategies and Tactics for Management. Washington, DC.: National Academy Press.

Moekassan, T.K., S. Sastrosiswojo, T. Rukmana, Susanto, I.S. Purnamasari, \& A. Kurnia. 2004. Status resistensi lima strain Plutella xylostella L. terhadap formulasi fipronil, deltametrin, profenofos, abamektin, dan Bacillus thuringiensis. J. Hort. 14(2): 84-90.

Nailufar, N., \& D. Prijono. 2017. Synergistic activity of Piper aduncum fruit and Tephrosia vogelii leaf extracts against the cabbage head caterpillar, Crocidolomia pavonana. J. ISSAAS. 23(1): 102-110.
Pitterna, T. 2012. Chloride channel activators/new natural products: avermectins and milbemycins. Pp. 1305-1326 in Krämer, W., U. Schirmer, P. Jeschke, \& W. Witschel (Eds.). Modern Crop Protection Compounds. 2nd ed. Weinheim: Wiley-VCH.

Prijono, D, A.M. Pusparini, H.A. Aini, \& Munawaroh. 2019. Susceptibility of the diamondback moth, Plutella xylostella (L.), from West Java, Indonesia to five non-classical insecticides. Int. J. Agric. Environ. Biores. 4(1): 51-60.

Rakhman, A., \& D. Prijono. 2015. Kerentanan Plutella xylostella dari Kecamatan Cipanas, Kabupaten Cianjur, Jawa Barat terhadap lima jenis insektisida komersial. Pp. 71-78 in Prosiding Seminar Nasional Perlindungan Tanaman II; Bogor, 13 Nov 2014. Bogor: Pusat Kajian Pengendalian Hama Terpadu. Institut Pertanian Bogor.

Rauf, A., D. Prijono, Dadang, I W. Winasa, \& D.A. Russell. 2005. Survey of Pest Control Practices of Cabbage Farmers in West Java, Indonesia. Cooperation between Department of Plant Pests and Diseases IPB (Indonesia) and Centre for Environmental Stress and Adaptation Research, LaTrobe University (Australia).

Robertson, J.L., H.K. Preisler, \& R.M. Russell. 20022003. PoloPlus: Probit and Logit Analysis. User's Guide. Petaluma: LeOra Software.

Sastrosiswojo, S., \& W. Setiawati. 1993. Hama-hama tanaman kubis dan cara pengendaliannya. Pp. 39-50 in Permadi, A.H. \& Sastrosiswojo, S. (Eds.). Kubis. Bandung: Balai Penelitian Hortikultura.

Sastrosiswojo, S., T.S. Uhan, \& R. Sutarya. 2005. Penerapan Teknologi PHT pada Tanaman Kubis. Bandung: Balai Penelitian Tanaman Sayuran.

Scott, I.M., H.R. Jensen, B.J.R. Philogene, \& J.T. Arnason. 2008. A review of Piper spp. (Piperaceae) phytochemistry, insecticidal activity and mode of action. Phytochem. Rev. 7(1): 65-75.

Sparks, T.C. 2013. Insecticide discovery: An evaluation and analysis. Pestic. Biochem. Physiol. 107(1): 8-17.

Syahroni, Y.Y., \& D. Prijono. 2013. Aktivitas insektisida campuran ekstrak buah Piper aduncum (Piperaceae) dan Sapindus rarak (Sapindaceae) terhadap larva Crocidolomia pavonana. J. Entomol. Indones. 10(1): 39-50.

$\mathrm{Yu}$, S.J. 2008. The Toxicology and Biochemistry of Insecticides. Boca Raton: CRC Press.

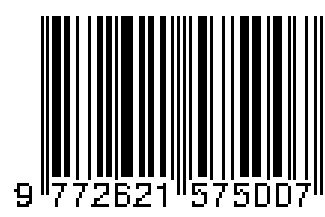

